\title{
A new species, Sagediopsis vasilyevae, and other lichenicolous fungi from Zabaikal'skii Territory of Russia, southern Siberia
}

\author{
Mikhail P. Zhurbenko' ${ }^{1}$ Lidiya S. Yakovchenko ${ }^{2}$ \\ ${ }^{1}$ Laboratory of the Systematics and Geography of Fungi, Komarov Botanical Institute, Russian Academy of Sciences, \\ Professora Popova str., 2, St. Petersburg, 197376, Russia. \\ E-mail: zhurb58@gmail.com \\ ${ }^{2}$ Laboratory of Lower Plants, Institute of Biology and Soil Science, Far Eastern Branch of Russian Academy of Sciences, \\ Stoletija Vladivostoka Avenue, 159, Vladivostok, 690022, Russia; Laboratory of Cryptogamic Biota, Botanical Garden- \\ Institute Far Eastern Branch of Russian Academy of Sciences, Makovskogo str., 142, Vladivostok, 690024, Russia. \\ E-mail: lidiyakovchenko@mail.ru
}

\begin{abstract}
Thirty seven species of lichenicolous fungi are reported from southern Siberia. Sagediopsis vasilyevae (on Rhizocarpon inarense) is described as new to science. Rosellinula haplospora is new to Russia. Abrothallus peyritschii, Arthonia apotheciorum and Lichenostigma cosmopolites are new to Siberia. Cetraria is a new host genus for Stigmidium microcarpum. Ameroconium cladoniae and Plectocarpon hypogymniae are newly documented on Cladonia alaskana and Hypogymnia tubulosa correspondingly.
\end{abstract}

\section{INTRODUCTION}

Lichenicolous fungi of Siberia are comparatively well studied only in its arctic part (Zhurbenko, 2007, 2009a,b). Information on their diversity in southern Siberia is still very scant (Zhurbenko \& Davydov, 2000; Zhurbenko \& Otnyukova, 2001; Zhurbenko, 2012b). Herewith we try to slightly fill this gap and report from its territory 37 species, one of which is new to Russia and three new to Siberia. One species is described as new to science; pertinent notes on taxonomy, biogeography and ecology of the treated fungi are provided.

The study is based on material from Sokhondinskii Reserve (43 specimens) and Alkhanai National Park in Aginskii Buryatskii District (5 specimens) obtained during the lichenological investigations by the second author (Yakovchenko, 2009; Yakovchenko \& Galanina, 2009). Both territories are characterized by a sharply continental climate, mountainous terrain with the highest peaks Sokhondo Mt. (2505 m) and Alkhanai Mt. (1662 m) respectively and altitudinal vegetation belts ranging from forest-steppe to mountain tundra.

\section{MATERIAL AND METHODS}

The material was identified by the first author using Zeiss microscopes Stemi 2000-CS and Axio Imager A1 equipped with Nomarski dif- ferential interference contrast (DIC) optics. Microscopical examination was done in water, $10 \% \mathrm{KOH}(\mathrm{K})$, Lugol's iodine directly (I) or after a $\mathrm{KOH}$ pre-treatment $(\mathrm{K} / \mathrm{I})$ or Brilliant Cresyl blue. The length, breadth and length/breadth ratio $(1 / b)$ of asci, ascospores and conidia (when $\mathrm{n}>10)$ are given as: $(\min -)\{\mathrm{X}-\mathrm{SD}\}-\{\mathrm{X}+\mathrm{SD}\}(-\max )$, where min and max are the extreme values, $X$ the arithmetic mean, and SD the corresponding standard deviation. Measurements were taken from water mounts, unless otherwise indicated. The nomenclature of the host lichens follows Esslinger (2012). Examined specimens are deposited in the mycological herbarium of the V. L. Komarov Botanical Institute in Saint Petersburg, Russia (LE-Fungi).

\section{THE SPECIES}

All collections are from Zabaikal'skii Territory of Russia; all species except Stigmidium microcarpum are new to this territory.

Abrothallus Bertianus De Not. - Sokhondinskii Reserve, Agutsa River at $1 \mathrm{~km} \mathrm{~N}$ of Buninda Cabin, 4942'58.5"N, $111^{\circ} 22^{\prime} 49.6^{\prime \prime} \mathrm{E}$, alt. 1182 $\mathrm{m}$, Betula-Larix forest, on Melanohalea olivacea (lobes, apothecia; often on galls induced by Nesolechia oxyspora), 22.07.2008, L. S. Yakovchenko, LE 260994a. 
Note - Formerly known in Siberia only from Polar Ural (Zhurbenko, 2008).

Abrothallus CAerulescens I. Kotte - Sokhondinskii Reserve, $1 \mathrm{~km} \mathrm{~N}$ of Buninda Cabin, $49^{\circ} 42^{\prime} 58.5^{\prime \prime} \mathrm{N}, 111^{\circ} 22^{\prime} 49.6^{\prime \prime} \mathrm{E}$, alt. $1180 \mathrm{~m}$, Betula-Larix forest, on Xanthoparmelia stenophylla (thallus), 22.07.2008, L. S. Yakovchenko, LE 260924.

Note - Formerly known in Siberia from Polar Ural (Zhurbenko, 2008), vicinities of Krasnoyarsk (Zhurbenko, 2012b) and Tuva Republic (Zhurbenko \& Otnyukova, 2001).

ABRothallus PEYRITSChi (Stein) I. Kotte - Sokhondinskii Reserve, Sopkoyan Mt., 2 km NW of Verkhnyaya Enda Cabin, $49^{\circ} 35.987^{\prime} \mathrm{N}$, $110^{\circ} 46.578 ' \mathrm{E}$, alt. $1902 \mathrm{~m}$, Pinus pumila shrubs, on Vulpicida pinastri (thallus), 6.07.2007, L. S. Yakovchenko, LE 261194a.

Notes - Formerly known in Russia from Severnaya Osetiya Republic, Leningrad Region, Khabarovsk Territory and Kamchatka Territory (Vainio, 1899; Kuznetsova et al., 2007; Zhurbenko, 2007; Zhurbenko et al., 2012). New to Siberia.

Ameroconium cladoniae U. Braun \& Zhurb. - Sokhondinskii Reserve, Balbashnyi Mt., 49 48'57.7'N, 11051'54.8'"E, alt. $1864 \mathrm{~m}$, mountain lichen tundra with Pinus pumila, on Cladonia alaskana (podetia), 3.07.2007, L. S. Yakovchenko, LE 261164.

Note - This recently described species was known from Cladonia arbuscula and C. rangiferina (Zhurbenko \& Braun, 2013). Cladonia alaskana is a new host species.

ARthonia APOTHECIORUM (A. Massal.) Almq. - Sokhondinskii Reserve, Agutsa River at $1 \mathrm{~km} \mathrm{~N}$ of Buninda Cabin, 49 $42^{\prime} 58.5^{\prime \prime} \mathrm{N}, 111^{\circ} 22^{\prime} 49.6^{\prime \prime} \mathrm{E}$, alt. $1182 \mathrm{~m}$, Betula-Larix gmelinii forest, on Lecanora symmicta (apothecia) growing on Larix, 22.07.2008, L. S. Yakovchenko, LE 260983b.

Note - New to Siberia.

Arthonia stereocaulina (Ohlert) R. Sant. Sokhondinskii Reserve, near Verkhnii Bukukun Cabin at Bukukun River, $49^{\circ} 37.467 ' \mathrm{~N}$, $111^{\circ} 02.147^{\prime} \mathrm{E}$, alt. $1755 \mathrm{~m}$, Pinus sibirica-Larix gmelinii forest, on Stereocaulon tomentosum (phyllocladia), 10.08.2001, I. A. Galanina, LE 260965a.

Note - Frequently recorded in Russia, particularly in the Arctic (Zhurbenko, 2010).

BACHMANNIOMYCES UNCIALICOLA (Zopf) D. Hawksw. - Sokhondinskii Reserve, near Bukukun Lake, $49^{\circ} 41.310^{\prime} \mathrm{N}, 110^{\circ} 58.288^{\prime} \mathrm{E}$, alt. $1680 \mathrm{~m}$, Pinus sibirica-Larix gmelinii forest, on Cladonia amaurocraea (podetia), 29.06.2007, L. S. Yakovchenko, LE 260944.

Note - Formerly known in Siberia from Tuva Republic (Zhurbenko \& Otnyukova, 2001) and Taimyr Peninsula (Zhurbenko, 1998).

CAPRonia Peltigerae (Fuckel) D. Hawksw. - Sokhondinskii Reserve, Agutsa River at $1 \mathrm{~km} \mathrm{~N}$ of Buninda Cabin, 49 $42^{\prime} 58.5^{\prime \prime} \mathrm{N}, 111^{\circ} 22^{\prime} 49.6^{\prime \prime} \mathrm{E}$, alt. $1182 \mathrm{~m}$, Betula-Larix forest, on Peltigera leucophlebia (cephalodia, lobes), 22.07.2008, L. S. Yakovchenko, LE 261114.

Note - Formerly known in Siberia from Taimyr Peninsula and Yakutiya (Zhurbenko 2009b).

Cercidospora stereocaulorum (Arnold) Hafellner - Sokhondinskii Reserve, top of Tcagan-Ula Mt., $49^{\circ} 38.389^{\prime} \mathrm{N}, 111^{\circ} 03.493^{\prime} \mathrm{E}$, alt. $1938 \mathrm{~m}$, on Stereocaulon apocalypticum (phyllocladia), 24.07.2005, L. S. Yakovchenko, LE 260935.

Note - Frequently recorded in Russia, particularly in the Arctic (Zhurbenko, 2010).

Clypeococcum CETRARIae Hafellner - Sokhondinskii Reserve, Sopkoyan Mt., $2 \mathrm{~km}$ NW of Verkhnyaya Enda Cabin, $49^{\circ} 35.987^{\prime} \mathrm{N}, 110^{\circ} 46.578^{\prime} \mathrm{E}$, alt. $1902 \mathrm{~m}$, Pinus pumila shrubs, on Vulpicida pinastri (thallus), 6.07.2007, L. S. Yakovchenko, LE 261194b.

Notes - Formerly known in Siberia from Evenkiya (Zhurbenko \& Zhdanov, 2013) and arctic Yakutiya (Zhurbenko, 2002). Most reports of this species are from Cetraria islandica, but it has been reported from Vulpicida pinastrias well (Zhurbenko \& Zhdanov, 2013).

Endococcus NANELlus Ohlert - Sokhondinskii Reserve, near Verkhnii Bukukun Cabin at Bukukun River, 49 $37^{\prime} 34.4^{\prime \prime} \mathrm{N}, 111^{\circ} 02^{\prime} 11.9^{\prime \prime} \mathrm{E}$, alt. $1775 \mathrm{~m}$, Pinus sibirica-Larix gmelinii forest, on Stereocaulon tomentosum (phyllocladia, stems), 20.07.2005, L. S. Yakovchenko, LE 260955. 
Note - Frequently recorded in Russia, particularly in the boreal regions (Zhurbenko, 2010).

Endococcus RUgulosus Nyl. - Sokhondinskii Reserve, Sopkoyan Mt., $2 \mathrm{~km}$ NW of Verkhnyaya Enda Cabin, $49^{\circ} 35.987 ' \mathrm{~N}, 110^{\circ} 46.578^{\prime} \mathrm{E}$, alt. 1900 m, stone field among Pinus pumila shrubs, on Aspicilia sp. (thallus), 6.07.2007, L. S. Yakovchenko, LE 260964.

Note - Frequently recorded in Russia (Zhurbenko, 2007, 2009a,b).

Epicladonia sandstedei (Zopf) D. Hawksw. Sokhondinskii Reserve: near Verkhnii Bukukun Cabin at Bukukun River, $49^{\circ} 38^{\prime} 01.8^{\prime \prime} \mathrm{N}$, $111^{\circ} 02 ' 23.7^{\prime \prime E}$, alt. $1885 \mathrm{~m}$, alpine stone field, on Cladonia furcata (podetia), 15.07.2001, I. A. Galanina, LE 261134; near Bukukun Lake, $49^{\circ} 42^{\prime} 14.7 " \mathrm{~N}, 110^{\circ} 59^{\prime} 52.4^{\prime \prime} \mathrm{E}$, alt. $1800 \mathrm{~m}$, Pinus sibirica-Larix gmelinii forest, on Cladonia gracilis (podetia), 29.06.2007, L. S. Yakovchenko, LE 260914.

Note - Formerly known in Siberia only from Taimyr Peninsula (Zhurbenko, 1998).

EPINEPHROMA KAMchatica Zhurb. \& Stepanchikova - Sokhondinskii Reserve: KumylAliya River, near Agutsa Cabin, 49 $41^{\prime} 12.6^{\prime \prime} \mathrm{N}$, $111^{\circ} 26^{\prime} 00.4^{\prime \prime E}$, alt. 1180 m, Betula-Larix forest, on Nephroma helveticum (lobes) growing on mossy stones, 30.08.2009, L. S. Yakovchenko, LE 260943; 1.09.2009, L. S. Yakovchenko, LE 260923.

Notes - This recently described species was so far known only from Kamchatka Peninsula growing on Nephroma parile (Zhurbenko et al., 2012). In its type material pycnidia were immersed in a clypeus and dispersed over the upper surface of the host lobes. Conidia were more or less cuneiform, rounded at the apex and usually truncate at the base, (4.5-)6.5-8.5(-14.0) $\times$ (4.0-)4.5-5.5(-6.5) $\mu \mathrm{m}, 1 / \mathrm{b}=(1.0-) 1.2-1.8(-3.1)$, hyaline and with smooth walls. In the newly examined specimens pycnidia are mostly sessile on the host lobe margins, not associated with a clypeus and look like belonging to the lichen, only rarely semi-immersed in the central parts of the host lobes (Fig. 1). Conidia are of similar shape and size, (5.8-)7.3-9.9(-12.6) × (4.2-)4.7$5.7(-6.3) \mu \mathrm{m},(1 / \mathrm{b}=(1.1-) 1.3-2.1(-2.8)(\mathrm{n}=72)$, but becoming pale brown (K+ olive) and verruculose. It is noteworthy, that proper conidia of Nephroma species are bacilliform (James \& White, 2009). Examined material strongly recalls a Vouauxiomyces anamorph of the lichenicolous genus Abrothallus de Not. and possibly presents an asexual stage of Abrothallus welwitschii Tul. reported on Nephroma (Santesson et al., 2004; Zhurbenko et al., 2012), which conidiomata are so far not known with certainty (Diederich, 2004a).

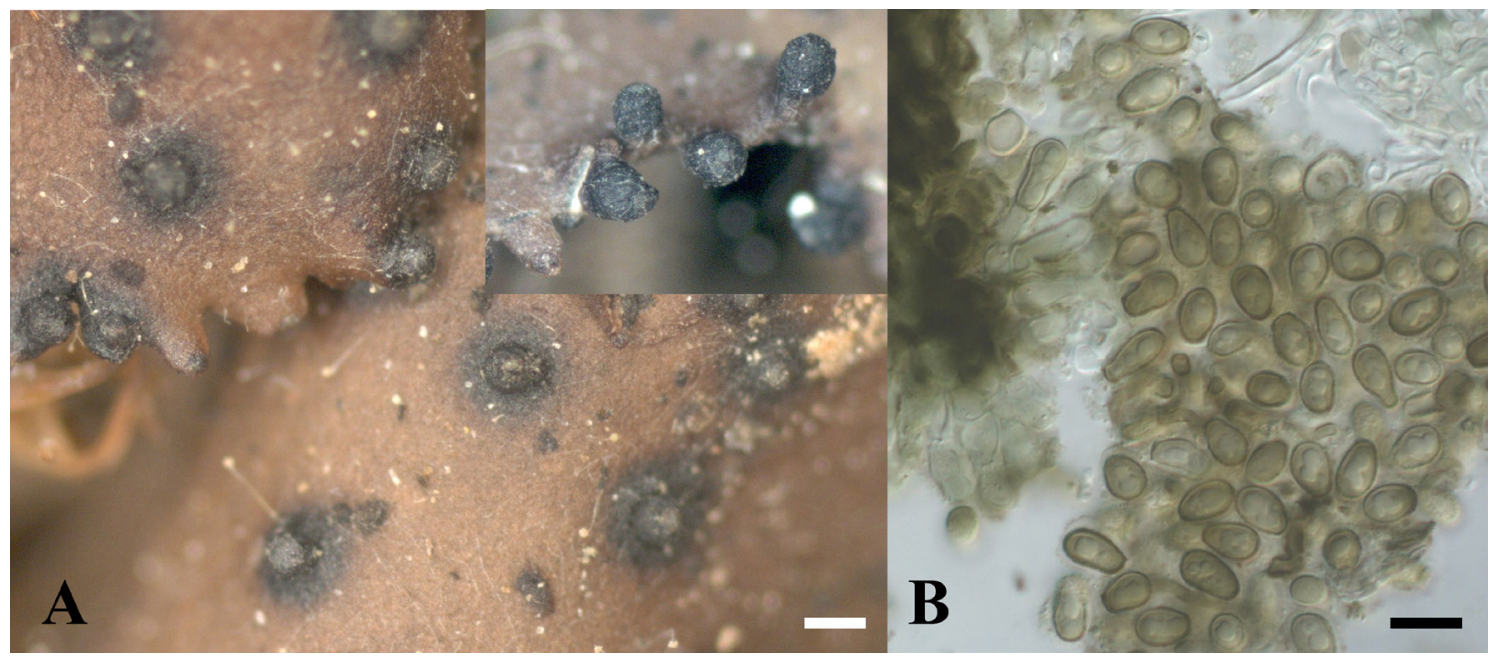

Fig. 1. Epinephroma kamchatica (A - LE 260923, B - LE 260943). A - pycnidia. B - conidia (in K). Bars: $A=200 \mu \mathrm{m} ; \mathrm{B}=10 \mu \mathrm{m}$. 
Lichenoconium LeCANORAE (Jaap) D. Hawksw. Sokhondinskii Reserve, Agutsa River at $1 \mathrm{~km} \mathrm{~N}$

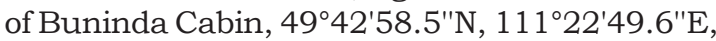
alt. $1182 \mathrm{~m}$, Betula-Larix gmelinii forest, on Lecanora symmicta (apothecia) growing on Larix, 22.07.2008, L. S. Yakovchenko, LE 260983a.

Note-Common throughout Russia (Zhurbenko, 2007, 2009a, b).

Lichenoconium usneae (Anzi) D. Hawksw. - Sokhondinskii Reserve, Agutsa River at $1 \mathrm{~km} \mathrm{~N}$ of Buninda Cabin, 49 $42^{\prime} 58.5^{\prime \prime} \mathrm{N}, 111^{\circ} 22^{\prime} 49.6^{\prime \prime} \mathrm{E}$, alt. $1182 \mathrm{~m}$, Betula-Larix forest, on Physcia aipolia (decaying lobe bases) growing on Betula, 22.07.2008, L. S. Yakovchenko, LE 260904.

Note - Formerly known in Siberia from Taimyr Peninsula (Zhurbenko, 2012a) and Olekminskii Reserve in Yakutiya (Zhurbenko \& Vershinina, 2014).

LiChenosticta ALCiCoRnaria (Linds.) D. Hawksw. - Sokhondinskii Reserve, near Verkhnii Bukukun Cabin at Bukukun River, 49 37'19.5'N, $111^{\circ} 02^{\prime} 17.6^{\prime \prime} \mathrm{E}$, alt. $1800 \mathrm{~m}$, Larix forest, on Cladonia sp. (basal squamules), 22.07.2005, L. S. Yakovchenko, LE 260954.

Note - Formerly known in Siberia from Yamal Peninsula and vicinities of Krasnoyarsk (Zhurbenko, 2008, 2012b).

Lichenostigma cosmopolites Hafellner \& Calat. - Sokhondinskii Reserve, near Verkhnii Bukukun Cabin at Bukukun River, 49 37'34.4'N, $111^{\circ} 02^{\prime} 11.9^{\prime \prime} \mathrm{E}$, alt. $1775 \mathrm{~m}$, boulders in Larix gmelinii-Pinus sibirica forest, on Xanthoparmelia stenophylla (thallus), 19.07.2005, L. S. Yakovchenko, LE 261034.

Notes - Formerly known in Russia only from Karelia Republic (Alstrup et al., 2005). New to Siberia.

LiCHENOSTIGMA MAURERI Hafellner - Alkhanai National Park, N slope of Alkhanai Mt., Kurlukhta top, $50^{\circ} 52.425^{\prime} \mathrm{N}, 113^{\circ} 19.8266^{\prime} \mathrm{E}$, alt. $1455 \mathrm{~m}$, Pinus sibirica-Larix gmelinii forest in upper forest belt, on Evernia esorediosa (thallus) growing on Larix dahurica, 7.07.2006, L. S. Yakovchenko, LE 260907. - Sokhondinskii Reserve: Agutsa River at $1 \mathrm{~km} \mathrm{~N}$ of Buninda Cabin, 4942'58.5'N, $111^{\circ} 22^{\prime} 49.6^{\prime \prime} \mathrm{E}$, alt. 1182 $\mathrm{m}$, Betula-Larix forest, on Usnea dasypoga (thal- lus) growing on Betula platyphylla, 22.07.2008, L. S. Yakovchenko, LE 260925; near Bukukunskoe Lake, $49^{\circ} 42^{\prime} 20.00^{\prime \prime} \mathrm{N}, 111^{\circ} 01^{\prime} 03.60^{\prime \prime} \mathrm{E}$, alt. $1838 \mathrm{~m}$, on Evernia esorediosa (thallus) growing on Larix bark, 1.07.2007, L. S. Yakovchenko, LE 260974; near Bukukunskoe Lake, 4941'31'N, $110^{\circ} 58^{\prime} 29^{\prime \prime E}$, alt. $1680 \mathrm{~m}$, Pinus sibirica-Larix forest, on Evernia mesomorpha (thallus) growing on Pinus bark, 1.07.2007, L. S. Yakovchenko, LE 261084.

Note-Common throughout Russia (Zhurbenko, 2007, 2009b).

Muellerella Pygmaea (Körb.) D. Hawksw. - Sokhondinskii Reserve, $\mathrm{N}$ coast of Bukukunskoe

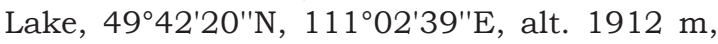
subalpine belt with Pinus sibirica, on Rhizocarpon geographicum (thallus), 30.06.2007, L. S. Yakovchenko, LE 261166.

Note - Frequently recorded in Russia, particularly from the Arctic (Zhurbenko, 2007, 2009b).

Muellerella ventosicola (Mudd) D. Hawksw. - Sokhondinskii Reserve, Balbashnyi Mt., $49^{\circ} 48^{\prime} 57.7^{\prime \prime} \mathrm{N}, 110^{\circ} 51^{\prime} 54.8^{\prime \prime} \mathrm{E}$, alt. $1864 \mathrm{~m}$, mountain lichen tundra with Pinus pumila, on Rhizocarpon alpicola (thallus), 3.07.2007, L. S. Yakovchenko, LE 260915).

Note - Formerly known in non-Arctic Siberia only from Altai Republic (Zhurbenko \& Davydov, 2000).

Nesolechia oxyspora (Tul.) A. Massal. - Alkhanai National Park, 50 52.077'N, $113^{\circ} 22.107 ' \mathrm{E}$, alt. 1535 m, Pinus sibirica-Larix gmelinii forest in the upper forest belt (near the pilgrim trail), on Parmelia sulcata (thallus) growing on Larix gmelinii, 11.07.2006, L. S. Yakovchenko, LE 261088. - Sokhondinskii Reserve: Agutsa River at $1 \mathrm{~km} \mathrm{~N}$ of Buninda Cabin, 49 $42^{\prime} 58.5^{\prime \prime} \mathrm{N}$, $111^{\circ} 22^{\prime} 49.6^{\prime \prime E}$, alt. $1180 \mathrm{~m}$, Betula-Larix forest, on Parmelia sulcata (thallus) growing on Betula, 22.07.2008, L. S. Yakovchenko, LE 261104; on Melanohalea olivacea (lobes), 22.07.2008, L. S. Yakovchenko, LE 260994b; Sokhondo Mt., $49^{\circ} 40.497 ' \mathrm{~N}, 111^{\circ} 02.751^{\prime} \mathrm{E}$, alt. $2100 \mathrm{~m}$, on Melanohalea olivacea (thallus) growing on twig, 24.07.2005, L. S. Yakovchenko, LE 261118.

Note-Common throughout Russia (Zhurbenko, 2007, 2009a, 2012b; Zhurbenko et al., 2012). 
Niesslia Cladonitcola D. Hawksw. \& W. Gams Sokhondinskii Reserve, Sokhondo Mt., near Bukukunskoe Lake, $49^{\circ} 42.474^{\prime} \mathrm{N}, 111^{\circ} 04.749^{\prime} \mathrm{E}$, alt. $2295 \mathrm{~m}$, on Cladonia furcata (moribund podetia), 24.07.2005, L. S. Yakovchenko, LE 261004.

Note - Formerly known in Siberia from Taimyr Peninsula (Zhurbenko \& Alstrup, 2004) and from an unknown place within Krasnoyarsk Territory (Alstrup, 2004).

Phacopsis CEPHALOdioides (Nyl.) Triebel \& Rambold - Alkhanai National Park, 50 52.077'N, $113^{\circ} 22.107^{\prime} \mathrm{E}$, alt. $1535 \mathrm{~m}$, Pinus sibirica- Larix gmelinii forest, in the upper forest belt (near the pilgrim trail), on Hypogymnia physodes (thallus) growing on Larix gmelinii, 11.07.2006, L. S. Yakovchenko, LE 260945.

Note - Formerly known in Siberia from Tuva Republic (Zhurbenko \& Otnyukova, 2001) and Irkutsk region (Zhurbenko \& Vershinina, 2014).

Phacopsis huUskoneniI Räsänen - Sokhondinskii Reserve, near Verkhnii Bukukun Cabin at Bukukun River, 49 37'34.4'N, $111^{\circ} 02^{\prime} 11.9^{\prime \prime} \mathrm{E}$, alt. 1775 m, Pinus sibirica-Larix gmelinii forest, on Bryoria simplicior (thallus), 20.07.2005, L. S. Yakovchenko, LE 261154.

Note - Sporadically reported in boreal Siberia (Zhurbenko, 2009a, 2012b; Zhurbenko \& Zhdanov, 2013).

Plectocarpon hypogymniae Zhurb. \& Diederich - Sokhondinskii Reserve, Agutsa River at $1 \mathrm{~km} \mathrm{~N}$ of Buninda Cabin, 49 $42^{\prime} 58.5^{\prime \prime} \mathrm{N}$, $111^{\circ} 22^{\prime} 49.6^{\prime \prime E}$, alt. $1182 \mathrm{~m}$, Betula-Larix forest, on Hypogymnia tubulosa (lobes), 22.07.2008, L. S. Yakovchenko, LE 261074. - Alkhanai National Park, $50^{\circ} 52.077^{\prime} \mathrm{N}, 113^{\circ} 22.107 ' \mathrm{E}$, alt. $1535 \mathrm{~m}$, Pinus sibirica-Larix gmelinii forest, in the upper forest belt (near the pilgrim trail), on Hypogymnia bitteri (thallus) growing on Larix gmelinii, 11.07.2006, L. S. Yakovchenko, LE 261064.

Note - The species was so far known from the type collected in Tuva Republic of Russia (Zhurbenko et al., 2008). and from Olekminskii Reserve in Yakutiya (Zhurbenko \& Vershinina, 2014).

Polycoccum Pulvinatum (Eitner) R. Sant. - Sokhondinskii Reserve, Agutsa River at $1 \mathrm{~km} N$ of
Buninda Cabin, 4942'58.5' $\mathrm{N}, 111^{\circ} 22^{\prime} 49.6^{\prime \prime} \mathrm{E}$, alt. $1182 \mathrm{~m}$, Betula-Larix forest, on Physcia aipolia (lobes) growing on Betula, 22.07.2008, L. S. Yakovchenko, LE 260984.

Note - Formerly known in Siberia from Yakutiya and Chukotka (Zhurbenko, 2009b).

Rosellinula haplospora (Th. Fr. \& Almq. ex Th. Fr.) R. Sant. - Alkhanai National Park, northern slope of Dimchik-Sume Mt., 50 $50.060^{\prime} \mathrm{N}$, $113^{\circ} 23.424^{\prime} \mathrm{E}$, alt. $1162 \mathrm{~m}$, rocks in Larix-Betula forest, on Aspicilia sp. (thallus), 22.09.2009, L. S. Yakovchenko, LE 261058.

Notes - Ascospores are somewhat smaller than reported by Hafellner (1985), viz. (5.5$5.8-8.8(-11.1) \times(3.5-) 4.1-4.9(-5.4) \mu \mathrm{m}, 1 / \mathrm{b}=$ $(1.3-) 1.4-1.8(-2.4)(\mathrm{n}=34)$ vs. $7-11 \times 4.5-6.5$ $\mu \mathrm{m}$. Formerly known in Asia only from Turkey (Halici \& Candan, 2007). New to Russia.

\section{SAGEDIOPSIS VASILYEVAE Zhurb. sp. nov.}

MycoBank No.: MB 809173.

Lichenicolous fungus growing on species of $R h i-$ zocarpon. Similar to Sagediopsis aquatica, but with longer ascospores, (37.5-)41.7-50.3(-53.0) $\times(2.5-) 2.9-3.5(-3.8) \mu \mathrm{m}$.

Typus: Russia, southern Siberia, Zabaikal'skii Territory, Sokhondinskii Reserve, Sopkoyan Mt., $2 \mathrm{~km}$ NW of Verkhnyaya Enda Cabin, $49^{\circ} 35.987^{\prime} \mathrm{N}, 110^{\circ} 46.578^{\prime} \mathrm{E}$, alt. $1902 \mathrm{~m}$, stone field among Pinus pumila shrubs, on Rhizocarpon inarense (thallus), 6.07.2007, L. S. Yakovchenko, LE 260905 - holotypus.

Description (Fig. 2) - Ascomata perithecioid, not clypeate, but with markedly thickened above wall, black, more or less subglobose to obovate, often flattened above, slightly protruding, exposed part coarsely radially split and becoming dentate, opening by an irregular broad pore, sometimes finally gaping up to 70 $\mu \mathrm{m}$ across, (60-)100-200 $\mu \mathrm{m}$ diam., discrete to adjacent. Exciple in cross section more or less pseudoparenchymatous, consisting of two layers. The outer layer composed of rounded to ellipsoid cells with walls $1-2 \mu \mathrm{m}$ thick; apically dark brown, mostly 30-50 $\mu \mathrm{m}$ thick, composed of 6-12 cell layers; laterally dark to medium brown, 15-30 $\mu \mathrm{m}$ thick, composed of 4-8 cell layers; basally pale to medium brown, 5-10 $\mu \mathrm{m}$ thick, composed of 2-4 cell layers; K+ lighter yel- 


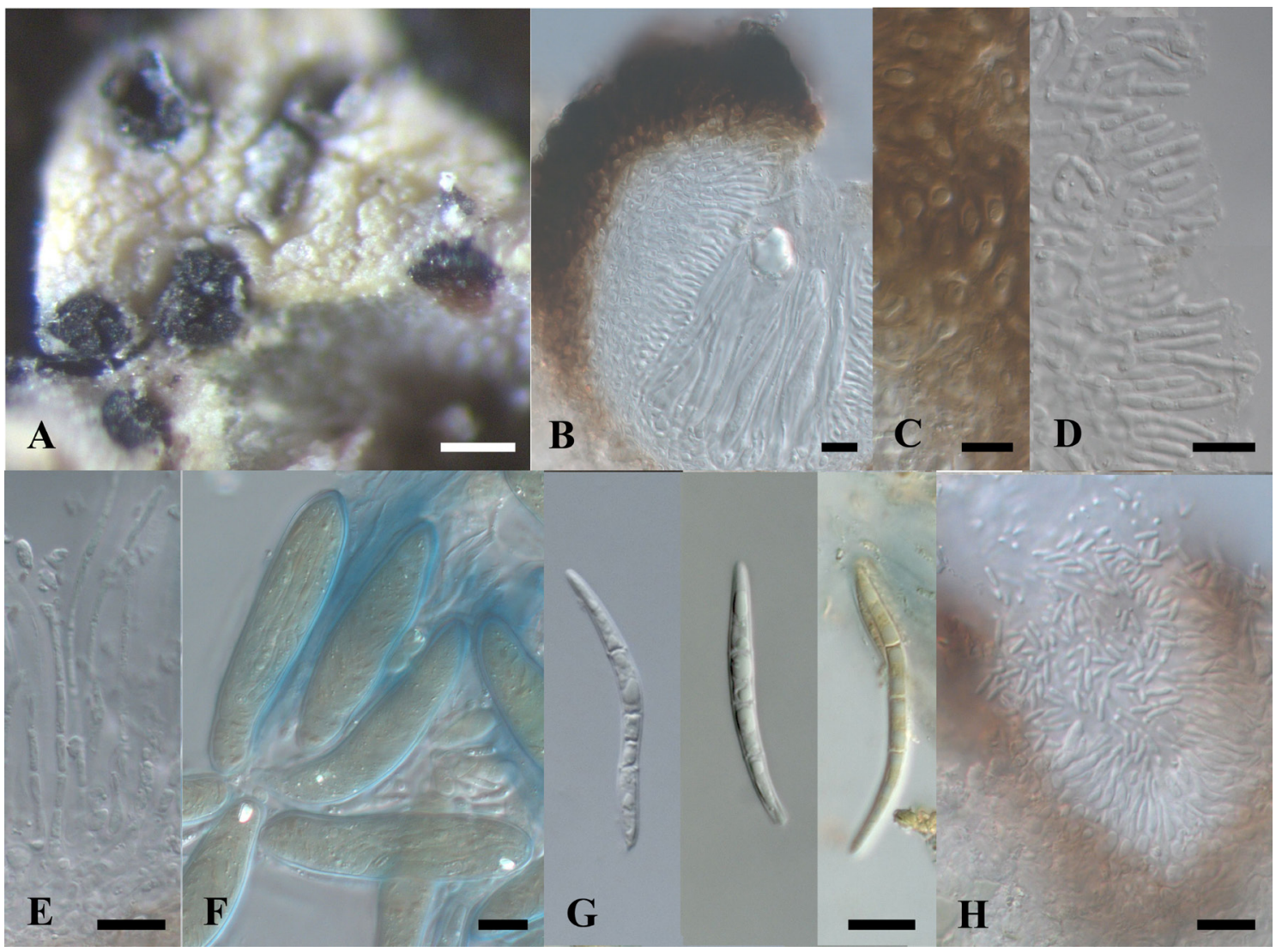

Fig. 2. Sagediopsis vasilyevae (holotype). A - ascomata habitus, note cross sectioned ascoma on the right. B - ascoma section (in water). C - exciple in cross section (in K). D - periphysoids (in K). $\mathrm{E}$ - interascal filaments (in water). F-asci (in $\mathrm{K} / \mathrm{I}$ ). $\mathrm{G}$ - ascospores (in water or I, the rightmost). $\mathrm{H}$ - conidioma with conidia in cross section (in water). Bars: $\mathrm{A}=100 \mu \mathrm{m}$; $\mathrm{B}-\mathrm{H}=10 \mu \mathrm{m}$.

low to orange-brown. The inner layer colourless; laterally 15-25 $\mu \mathrm{m}$ thick, composed 4-8 layers of rounded to ellipsoid cells; basally 5-10 $\mu \mathrm{m}$ thick, composed of 2-4 layers of tangentially elongated cells forming subhymenium. Ostiolar canal and periphyses not observed. Periphysoids abundant, hyaline, not swollen at the apex, ca. 10-20 × 1-1.5 $\mu \mathrm{m}, 1-4$-septate, branches and anastomoses not observed, densely lining upper part of ascomatal cavity and merging below with interascal filaments developing from its basal part. Interascal filaments paraphysis-like, persistent, longer then asci, cylindrical, not thickened at the apex, (1-)1.5(-2) $\mu \mathrm{m}$ diam., not or rarely scarcely branched, septate, not or slightly constricted at the septa, somewhat guttulate. Hymenial gel I and $\mathrm{K} / \mathrm{I}+$ immediately blue throughout. Asci narrowly ellipsoid to narrowly clavate, rounded at the base, mostly without distinct foot, wall 0.5-1 $\mu \mathrm{m}$ thick throughout or slightly thickened at the apex up to $2.5 \mu \mathrm{m}$, without distinct apical structures, (50.5-)52-64(-69) $\times(9.5-) 10.5-14.5(-17) \mu \mathrm{m}(\mathrm{n}=15$, in I or K/I), 8-spored, wall I and K/I+ evenly blue. Ascospores hyaline, elongate-bacilliform to acicular, acuminate at both ends, straight or somewhat curved (artefact ?) in microscopic slides, (37.5)41.7-50.3(-53.0) × (2.5-)2.9-3.5(-3.8) $\mu \mathrm{m}, 1 / \mathrm{b}$ $=(11.1-) 12.5-16.9(-20.0)(\mathrm{n}=26$, in water or I), $3(-4)$-septate, not constricted at the septa, guttulate, with thin and smooth wall, non-halonate, arranged in an ascus in a fascicle. Conidiomata sac-shaped, ca. $50 \times 70 \mu \mathrm{m}$, with pale brown wall ca. $10 \mu \mathrm{m}$ thick. Conidiogenous cells lageni- 
form, ca. $7-10 \times 2-3 \mu \mathrm{m}(\mathrm{n}=5)$. Conidia hyaline, bacilliform, (3.7-)3.9-4.5(-4.9) × 1.2-1.4(-1.5) $\mu \mathrm{m}, 1 / \mathrm{b}=(2.6-) 2.9-3.5(-3.9)(\mathrm{n}=34$, in I) $\mu \mathrm{m}$, aseptate. Pathogenicity not observed.

Etymology - The species is named after Dr. Larissa N. Vasilyeva to honor her outstanding contribution to mycology.

Notes - Placement of the new species in the genus Sagediopsis (Sacc. \& D. Sacc.) Vain. (Adelococcaceae) requires further assessment as the latter is characterized by hemiamyloid hymenial gel and thick-walled asci (Hoffmann \& Hafellner, 2000: 99). However, hymenial gel of the type species of the genus Sagediopsis aquatica (Stein) Triebel is also I+ pale blue, staining red only by concentrated Lugol solution (Rambold et al., 1990) and the depiction of its ascus wall (op. cit., Fig. 7B) fits well the examined material. Within the genus, Sagediopsis vasilyevae shows most similarity with $S$. aquatica referring to subgen. Sagediopsis (Sacc.) Vain., which is characterized by asci with poorly developed ocular chamber and bacilliform to acicular ascospores (Hafellner, 1993). Sagediopsis aquatica differs from $S$. vasilyevae by its clypeate ascomata, a peridium bearing brown, long-celled hyphae around ostiolum, (0-)3(-6)-septate, shorter ascospores, $(22-) 27-36(-45) \times(2.5-) 3-3.5(-4) \mu \mathrm{m}$ and its different host lichen Koerberiella wimmeriana growing on wet rocks in humid places (Rambold et al., 1990). Respecting the other lichenicolous ascomycetes with immersed dark brown perithecioid ascomata and colourless, bacilliform, vermiform or acicular, septate ascospores Sagediopsis vasilyevae also resembles species of Sarcopyrenia Nyl. (Sordariomycetes, genera incertae sedis) and Spirographa Zahlbr. (Helotiales, genera incertae sedis). Species of the former differ from the new species in having ascomata with an involucrellum, evanescent interascal filaments, and I- hymenial gel and asci (Navarro-Rosinés $\&$ Hladun, 2004), species of the latter differ by the absence of distinct periphysoids, in having at first closed, later deeply urceolate ascomata, 16-32-spored asci and I and K/I- hymenial gel and asci (Diederich, 2004b). By its asci with I+ blue wall and some other ascocarp characteristics Sagediopsis vasilyevae resembles species of Epigloeaceae and Protothelenellaceae (Cannon $\&$ Kirk, 2007). The former differ from the new species, for instance, in having superficial ascomata, which are composed of thin-walled hyphae and immersed in a thin gelatinous algal film. The latter can be distinguished by asci with I+ blue apical ring and usually muriform ascospores.

SphaEREllothecium Reticulatum (Zopf) Etayo Sokhondinskii Reserve: Agutsa River at $1 \mathrm{~km} \mathrm{~N}$ of Buninda Cabin, 4942'58.5"N, $111^{\circ} 22^{\prime} 49.6^{\prime \prime} \mathrm{E}$, alt. $1182 \mathrm{~m}$, Betula-Larix forest, on Hypogymnia physodes (lobes), 22.07.2008, L. S. Yakovchenko, LE 261184; near Verkhnii Bukukun Cabin at Bukukun River, $49^{\circ} 38.175^{\prime} \mathrm{N}, 111^{\circ} 00.498^{\prime} \mathrm{E}$, alt. $1551 \mathrm{~m}$, Pinus sibirica-Larix gmelinii forest, on Hypogymnia physodes (lobes), 28.06.2007, L. S. Yakovchenko, LE 260934).

Note - Frequently recorded in Russia (Zhurbenko, 2007, 2009a, b; Zhurbenko \& Otte, 2012).

SPHAERELLOTHECIUM cf. STEREOCAULORUM Zhurb. \& Triebel - Sokhondinskii Reserve, near Verkhnii Bukukun Cabin at Bukukun River, $49^{\circ} 37.432^{\prime} \mathrm{N}$, $111^{\circ} 02.214^{\prime} \mathrm{E}$, alt. $1751 \mathrm{~m}$, Pinus sibirica-Larix gmelinii forest, on Stereocaulon tomentosum (phyllocladia, sometimes on its bleached portions), 10.08.2001, I. A. Galanina, LE 260965b.

Notes - The species has hyaline to occasionally pale olive, $1(-3)$-septate ascospores and characteristically grows in the epinecral layer of etomentose, naked stems of Stereocaulon spp. (Zhurbenko \& Triebel, 2008). In the examined material the ascospores were hyaline, 1-septate, and the fungus was not associated with epinecral layer of the host's stems. The only other Sphaerellothecium species known on Stereocaulon is S. cladoniae (Alstrup \& Zhurb.) Hafellner, which differs from the examined material in its shorter ascospores, (7.5-)8.5-11(-12.5) × (3)3.5-4.5(-5) $\mu \mathrm{m}$ (Zhurbenko \& Triebel, 2008) vs. (9.3-) 10.6-15.4(-16.0) × (3.1-)3.7-4.9(-5.4) $\mu \mathrm{m}$, $1 / \mathrm{b}=(2.4-) 2.7-3.3(-3.5)(\mathrm{n}=21)$. So far Sphaerellothecium stereocaulorum has been reported only from the northern regions of the Holarctic (Zhurbenko \& Triebel, 2008; Brackel, 2010).

"Stigmidium" Eucline (Nyl.) Vězda - Sokhondinskii Reserve, Sopkoyan Mt., $2 \mathrm{~km}$ NW of Verkhnyaya Enda Cabin, $49^{\circ} 35.987^{\prime} \mathrm{N}, 110^{\circ} 46.578^{\prime} \mathrm{E}$, alt. 1902 m, stone field among Pinus pumila shrubs, on Varicellaria lactea (thallus), 6.07.2007, L. S. Yakovchenko, LE 261174.

Note - Formerly known in Russia only from Taimyr Peninsula (Zhurbenko, 2009a). 
Stigmidium MiCROCARPUm Alstrup \& J.C. David Sokhondinskii Reserve, Sokhondo Mt., near Bukukunskoe Lake, 49 42.474' $\mathrm{N}, 111^{\circ} 04.749^{\prime} \mathrm{E}$, alt. $2295 \mathrm{~m}$, on Cetraria laevigata (over the entire lobe surface), 24.07.2005, L. S. Yakovchenko, LE 261013.

Notes - Ascomata embedded in stromatic tissue composed of brown hyphae, producing on the host lobes well-delimited, brown then black necrotic patches up to $2 \mathrm{~mm}$ lengthways, finally falling away (Fig. 3). Asci 25-32(-37) $\times$ (5.5-)7-9(-9.5) $\mu \mathrm{m}(\mathrm{n}=12$, in $\mathrm{K} / \mathrm{I})$. Ascospores mostly hyaline, smooth-walled and 1-septate, rarely pale brown, verruculose and 2 -septate, (6.5-)6.9-8.3(-9.3) × (2.3-)2.4-3.0(-3.2) $\mu \mathrm{m}$, $1 / \mathrm{b}=(2.5-) 2.6-3.0(-3.2)(\mathrm{n}=33$, in $\mathrm{K}$ or $\mathrm{K} / \mathrm{I})$. Stigmidium microcarpum was described from Flavocetraria cucullata (Alstrup, 1993) and subsequently also reported on species of Vulpicida (Zhurbenko, 2009a). Cetraria is a new host genus.

Stigmidium PSEUdopeltideae Cl. Roux \& Triebel - Sokhondinskii Reserve: Agutsakan River, $2 \mathrm{~km} \mathrm{~N}$ of Agutsakan Cabin, 49 $36.611^{\prime} \mathrm{N}$, $111^{\circ} 19.477^{\prime} \mathrm{E}$, alt. $1125 \mathrm{~m}$, Betula platyphylla forest with Rhododendron dahurica near the river, on Peltigera canina (thallus), 23.07.2006, L. S. Yakovchenko, LE 261148; Agutsa River at $1 \mathrm{~km} \mathrm{~N}$ of Buninda Cabin, 49 $42^{\prime} 58.5^{\prime \prime} \mathrm{N}$, $111^{\circ} 22^{\prime} 49.6^{\prime \prime E}$, alt. 1182 m, Betula-Larix forest, on Peltigera canina (lobes), 22.07.2008, L. S. Yakovchenko, LE 261124.

Note - Formerly known in Siberia from the Arctic (Severnaya Zemlya and Sverdrupa Island in the Kara Sea) and Altai Republic (Zhurbenko, 2009b).

Stigmidium tabacinae (Arnold) Triebel - Sokhondinskii Reserve, near Buninda Cabin, $49^{\circ} 42^{\prime} 22^{\prime \prime} \mathrm{N}, 111^{\circ} 22^{\prime} 03^{\prime \prime} \mathrm{E}$, alt. $1400 \mathrm{~m}$, sparse Pinus sylvestris forest on steppe S-exposed slope, on Toninia tristis ssp. asiae-centralis (thallus), 6.08.2001, L. S. Yakovchenko, LE 261138.

Note - Formerly known in Siberia only from arctic Yakutiya (Zhurbenko, 2009a).

Syzygospora Bachmannil Diederich \& M.S. Christ. - Sokhondinskii Reserve, near Bukukun Lake, $49^{\circ} 42^{\prime} 14.7 " \mathrm{~N}, 110^{\circ} 59^{\prime} 52.4^{\prime \prime E}$, alt. 1800 m, Pinus sibirica-Larix gmelinii forest, on Cladonia cornuta (podetia), 29.06.2007, L. S. Yakovchenko, LE 261144.

Note - Formerly known in Siberia only from Sverdlovsk Region (Shiryaev et al., 2010).

Tremella hypogymniae Diederich \& M.S. Christ. Sokhondinskii Reserve, Agutsa River at $1 \mathrm{~km} \mathrm{~N}$ of Buninda Cabin, 4942'58.5'N , 111 ${ }^{\circ} 22^{\prime} 49.6^{\prime \prime} \mathrm{E}$,

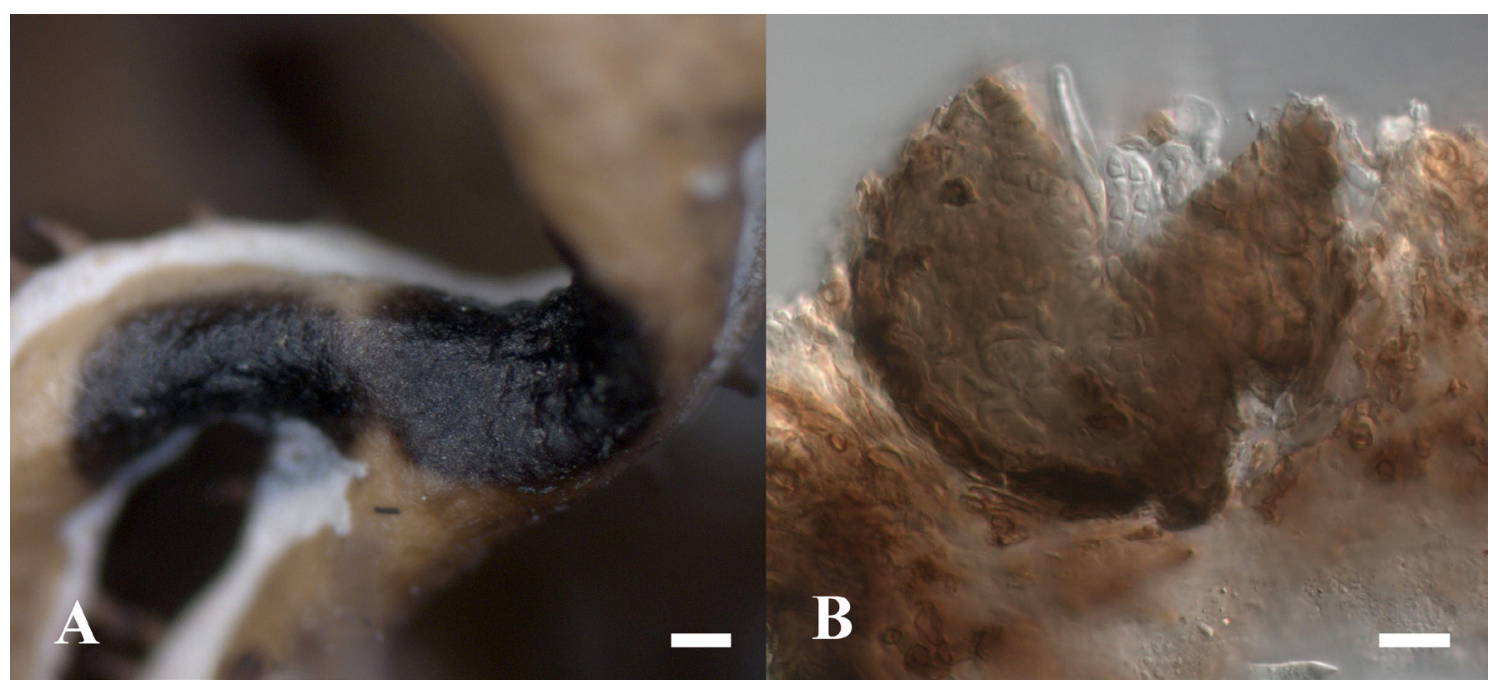

Fig. 3. Stigmidium microcarpum (LE 261013). A - necrotic patch with immersed ascomata. B ascoma immersed in stroma (in water). Bars: $A=200 \mu \mathrm{m} ; \mathrm{B}=10 \mu \mathrm{m}$. 
alt. $1182 \mathrm{~m}$, Betula-Larix forest, on Hypogymnia tubulosa (thallus), 22.07.2008, L. S. Yakovchenko, LE 261054.

Note - Formerly known in Siberia from Sverdlovsk Region, Krasnoyarsk Territory and Altai Republic (Zhurbenko \& Davydov, 2000; Shiryaev et al., 2010; Zhurbenko, 2012b; Zhurbenko \& Zhdanov, 2013).

\section{ACKNOWLEDGEMENTS}

Irina A. Galanina kindly permitted to include into this treatment three specimens of lichenicolous fungi collected by her. LY thanks professor Alexander V. Galanin as well as the director of Sokhondinskii Reserve Victor I. Yashnov, vice director Evgenii E. Malkov and senior inspector of the reserve Roman A. Dianov for the help in conducting field studies. Studies of LY are supported by the grant of Russian Foundation for Basic Research 13-04-01453a. MZh thanks Vadim A. Bakalin and Pavel V. Krestov for their hospitality during his visit to the Botanical Garden-Institute in Vladivostok.

\section{REFERENCES}

Alstrup, V. 1993. News on lichens and lichenicolous fungi from the Nordic countries. Graphis Scripta 5(2): 96-104.

Alstrup, V. 2004. New records in distribution of lichens and lichenicolous fungi. Graphis Scripta 16(2): 46-57.

Alstrup, V., Zavarzin, A. A., Kocourcova, J., Kravchenko, A. V., Fadeeva, M. A. \& Shiefelbein, U. 2005. Lichens and lichenicolous fungi found in Northern Ladoga area (Republic of Karelia) during the international fieldtrip in August 2004, prior to the fifth congress of International Lichenological Association. Trudy Karelskogo nauchnogo tsentra RAN (Petrozavodsk) 5: 3-15.

Brackel, W. v. 2010. Some lichenicolous fungi and lichens from Iceland, including Lichenopeltella uncialicola sp. nov. Herzogia 23: 93-109. http:// dx.doi.org/10.13158/heia.23.1.2010.93

Cannon, P. F. \& Kirk, P. M. 2007. Fungal Families of the World. CAB International. $456 \mathrm{pp}$.

Diederich, P. 2004a. Abrothallus. In: Nash III, T. H., Ryan, B. D., Diederich, P., Gries, C., Bungartz, F. (eds.). Lichen Flora of the Greater Sonoran Desert Region, Vol. 2. Lichens Unlimited, Arizona State University, Tempe, Arizona, pp. 626-630.

Diederich, P. 2004b. Spirographa. In: Nash III, T. H., Ryan, B. D., Diederich, P., Gries, C., Bungartz, F. (eds.). Lichen Flora of the Greater Sonoran Desert
Region, Vol. 2. Lichens Unlimited, Arizona State University, Tempe, Arizona, pp. 702-703.

Esslinger, T. L. 2012. A cumulative checklist for the lichen-forming, lichenicolous and allied fungi of the continental United States and Canada. North Dakota State University. URL: http:/ / www.ndsu. edu/pubweb/ esslinge/chcklst/chcklst7.htm (First Posted 1 December 1997, Most Recent Version (\#18) 13 December 2012), Fargo, North Dakota. Consulted in January 2014.

Hafellner, J. 1985. Studien über lichenicole Pilze und Flechten III. Die Gattung Roselliniella Vainio emend. Haf. (Ascomycotina, Dothideales). Herzogia 7: 145-162.

Hafellner, J. 1993. Über Funde von lichenicolen Pilzen und Flechten im südlichen Norwegen. Herzogia 9: 749-768.

Halici, M. G. \& Candan, M. 2007. Notes on some lichenicolous fungi species from Turkey. Turkish Journal of Botany 31: 353-356.

Hoffmann, N. \& Hafellner, J. 2000. Eine Revision der lichenicolen Arten der Sammelgattungen Guignardia und Physalospora (Ascomycotina). Bibliotheca Lichenologica 77: 1-181.

James, P. W. \& White, F. J. 2009. Nephroma Ach. in Luyken (1809). In: Smith, C. W. et al. (eds). The Lichens of Great Britain and Ireland. The British Lichen Society, London, pp. 622-625.

Kuznetsova, E., Ahti, T. \& Himelbrant, D. 2007. Lichens and allied fungi of the Eastern Leningrad Region. Norrlinia 16: 1-62.

Navarro-Rosinés, P. \& Hladun, N. L. 2004. Sarcopyrenia. In: Nash III, T. H., Ryan, B. D., Diederich, P., Gries, C., Bungartz, F. (eds.). Lichen Flora of the Greater Sonoran Desert Region, Vol. 2. Lichens Unlimited, Arizona State University, Tempe, Arizona, pp. 690-691.

Rambold, G., Hertel, H. \& Triebel, D. 1990. Koerberiella wimmeriana (Lecanorales, Porpidiaceae) and its lichenicolous fungi. Lichenologist 22(3): 225-240. http: / dx.doi.org/10.1017/S0024282990000251

Santesson, R., Moberg, R., Nordin, A., Tønsberg, T. \& Vitikainen, O. 2004. Lichen-forming and lichenicolous fungi of Fennoscandia. Museum of Evolution, Uppsala University. 359 pp.

Shiryaev, A. G., Kotiranta, H., Mukhin, V. A., Stavishenko, I. V. \& Ushakova, N. V. 2010. Aphyllophoroid fungi of Sverdlovsk region, Russia : biodiversity, distribution, ecology and the IUCN threat categories (in Russian). Ekaterinburg : Goshchitskiy Publisher. 303 pp.

Vainio ("Wainio"), E. A. 1899. Lichenes e Caucaso et in peninsula Taurica annis 1884-1885 ab H. Lojka et M. a Déchy collecti. Természetrajzi Füzetek 22: 269-343.

Yakovchenko, L. S. 2009. The lichens of the Sokhondinskiy Biospheric Reserve (in Russian). V. L. Komarov Memorial Lectures [Vladivostok: Dal'nauka Publisher] 56: 120-151. 
Yakovchenko, L. S. \& Galanina, I. A. 2009. Biological diversity of the National Park "Alkhanay": results of contemporary studies. Lichens (in Russian). Proceedings of the National Park "Alkhanay" [Chita: Express Publisher] 1: 60-85.

Zhurbenko, M. P. 1998. Lichens and lichenicolous fungi from the north of Pyasino lake, Taimyr peninsula, Siberia. Folia Cryptogamica Estonica 32: 153-159.

Zhurbenko, M. P. 2002. Arthonia triebeliae (Arthoniales), a new lichenicolous fungus from the Arctic. Mycological Progress 1(2): 137-141. http:/ /dx.doi. org/10.1007/s 11557-006-0012-0

Zhurbenko, M. P. 2007. The lichenicolous fungi of Russia: geographical overview and a first checklist. Mycologia Balcanica 4: 105-124.

Zhurbenko, M. P. 2008. Lichenicolous fungi from Russia, mainly from its Arctic. II. Mycologia Balcanica 5(1-2): 13-22.

Zhurbenko, M. P. 2009a. Lichenicolous fungi and some lichens from the Holarctic. Opuscula Philolichenum 6: 87-120.

Zhurbenko, M. P. 2009b. Lichenicolous fungi and lichens from the Holarctic. Part II. Opuscula Philolichenum 7: 121-186.

Zhurbenko, M. P. 2010. Lichenicolous fungi and lichens growing on Stereocaulon from the Holarctic, with a key to the known species. Opuscula Philolichenum 8: 9-39.

Zhurbenko, M. P. 2012a. Lichenicolous fungi growing on Thamnolia, mainly from the Holarctic, with a worldwide key to the known species. Lichenologist 44(2): 147-177. http: / dx.doi.org/10.1017/ S0024282911000739

Zhurbenko, M. P. 2012b. New records of lichenicolous fungi from "Stolby" Reserve (Krasnoyarsk Territory) (in Russian, English summary). Novitates Systematicae Plantarum non Vascularium [St. Petersburg] 46: 92-95.

Zhurbenko, M. P. \& Alstrup, V. 2004. Lichenicolous fungi on Cladonia mainly from the Arctic. Acta Universitatis Upsaliensis, Symbolae Botanicae Upsalienses 34(1): 477-499.
Zhurbenko, M. P. \& Braun, U. 2013. Ameroconium cladoniae gen. et sp. nov. and Phoma psoromatis sp. nov., new anamorphic lichenicolous fungi from the Holarctic. Lichenologist 45(5): 583-591. http://dx.doi.org/10.1017/S0024282913000285

Zhurbenko, M. P. \& Davydov, E. A. 2000. Lichenicolous fungi and some lichens from the Russian Altai, southern Siberia. Folia Cryptogamica Estonica 37: 109-118.

Zhurbenko, M. P. \& Otnyukova, T. N. 2001. Lichenicolous fungi from the Sayan-Tuva Mountains, Southern Siberia, Russia. Folia Cryptogamica Estonica 38: 79-84.

Zhurbenko, M. P. \& Otte, V. 2012. Lichenicolous fungi from the Caucasus: new records and a first synopsis. Herzogia 25: 235-244. http://dx.doi. org/10.13158/heia.25.2.2010.235

Zhurbenko, M. P. \& Triebel, D. 2008. Three new species of Stigmidium and Sphaerellothecium (lichenicolous ascomycetes) on Stereocaulon. Mycological Progress 7: 137-145. http://dx.doi. org/10.1007/s11557-008-0559-z

Zhurbenko, M. P. \& Vershinina, S. E. 2014 Opegrapha bryoriae sp. nov. and other lichenicolous fungi from Asian Russia. Herzogia 27: 93-109.

Zhurbenko, M. P. \& Zhdanov, I. S. 2013. Melaspilea galligena sp. nov. and some other lichenicolous fungi from Russia. Folia Cryptogamica Estonica 50: 89-99. http://dx.doi.org/10.12697/ fce.2013.50.12

Zhurbenko, M., Diederich, P. \& Otnyukova, T. 2008. Plectocarpon hypogymniae (Roccellaceae), a new lichenicolous species from Siberia. Bryologist 111(2): 328-330. http://dx.doi. org/10.1639/0007-2745(2008)111[328:PHRAN $\mathrm{L}] 2.0 . \mathrm{CO} ; 2$

Zhurbenko, M. P., Himelbrant, D. E., Kuznetsova, E. S. \& Stepanchikova, I. S. 2012. Lichenicolous fungi from the Kamchatka Peninsula, Russia. Bryologist 115(2): 295-312. http://dx.doi. org/10.1639/0007-2745-115.2.295 